\title{
Tulit Ilona*
}

\section{A „JÁMBOR SZÁNDÉK”-TÓL AZ E-TANKÖNYVEKIG. AZ ERDÉLYI MAGYAR KÖZOKTATÁS TANKÖNYVEIRŐL}

\author{
Kulcsszavak: tankönyv, tankönyvfordítás, könyvjegyzék, tankönyvkritika, tankönyvkínálat
}

A közoktatás gondjairól szóló közbeszéd napjainkban többnyire anyagi vonzatú témákat érint (pedagógusbérek, ingázási pénzek, leállított iskolarehabilitációs programok, megvesztegetési összegek az érettségi vizsgákon stb.), kerülve az oktatás tartalmi, minőségi kérdéseit. Homályos a szakhatóságok felelősségi köre, még az országos képességfelmérések sokkoló eredményei kapcsán sincs hír az oktatásirányítás illetékeseinek felelősségvállalásáról, a társadalmi számonkérésről.

Az intézményi, szakmai háttér hiányából, a társadalmi közönyből (is) következően alig esik szó a tankönyvekről (a minőségükről egyáltalán nem), legfeljebb statisztikai adatokként szerepelnek a tanfelügyelőségek tanév eleji beszámolóiban.

A tankönyvek körüli általános csend s az időnkénti nagy felhajtás bizonyos „vívmányok” körül sokat elárul korunk oktatáspolitikájáról, oktatásirányításáról. A 8. osztályos földrajz- és történelemtankönyvek lefordítása (!) például akkora eseménynek számított 2011-ben, hogy egyik vezető politikus személyesen mutatta be őket, a sajtó kiemelten méltatta az eseményt. Ilyenkor úgy tünhet, hogy a tankönyv nálunk is - mint minden normális társadalomban közügy.

\section{TANKÖNYVJEGYZÉK, -PÁLYÁZATOK, -FORDÍTÁSOK}

A tanügyi törvény előírása szerint a hazai közoktatásban kizárólag a minisztérium által jóváhagyott tankönyvek használhatóak. Ez az előírás egyaránt érvényes a kötelező 10 osztályos

* Tulit Ilona (Barót, 1944.) magyar nyelv és irodalom szakot végzett (Babeș-Bolyai Tudományegyetem 1966), magyartanár (1966-1969): Nyárádszentimre, Ákosfalva, Székelyudvarhely 19691998, magyartanár Sepsiszentgyörgyön, szakfelügyelő a Kovászna Megyei Tanfelügyelőségen; szerkesztő (T3 kiadó Sepsiszentgyörgy, 1996-tól kezdve), tankönyvszerző: Jámbor szándék (Orbán Gyöngyivel): Alternatív tanterv a magyar nyelv és irodalom tanításához. Korunk Baráti Társaság, 1992.; Magyar irodalomolvasás, alternatív tankönyv az V. osztálynak. Sepsiszentgyörgy, 1994.; Magyar nyelvés irodalomolvasás, tankönyv az V. osztály számára. Sepsiszentgyörgy, 1998.; Magyar nyelv és irodalomolvasás, tankönyv a VI. osztály számára. Sepsiszentgyörgy, 1999.; Magyar nyelv és irodalomolvasás, tankönyv a VII. osztály számára. Sepsiszentgyörgy, 2000.; Magyar nyelv és irodalomolvasás, tankönyv a VIII. osztály számára. Sepsiszentgyörgy, 2000.; Magyar nyelv és irodalomolvasás, tankönyv a VIII. osztály számára. Sepsiszentgyörgy, 2000. (Zaláni Virág néven); további publikációi: Hagyományörzés - hagyományteremtés (iskolatörténet). Sepsiszentgyörgy, 1992.; A nyelvvédelem, az anyanyelvápolás elsó 10 évéröl = Nyelvét megtartó közösség - közösségét megtartó nyelv. Anyanyelvápolók Erdélyi Szövetsége, Sepsiszentgyörgy, 2012. I-es didaktikai fokozat: 1982. Az Anyanyelvápolók Erdélyi Szövetsége a Sütő András Nyelvôrzés-díjjal tüntette ki 2012-ben. 
oktatásra - ahol a tankönyvellátás ingyenes - és a 11-12. osztályokra is. A minisztérium évente megjelenteti az érvényes tankönyvek katalógusát, ennek alapján rendelnek tankönyvet a tanfelügyelöségek az 1-10. osztályosoknak, illetve az iskolák vagy magánszemélyek a 11-12.-eseknek, a katalógusban feltüntetett kiadóktól.

A „tankönyvkatalógusba vezetô út” a minisztérium által az érvényes tantárgyi programok alapján meghirdetett tankönyvpályázat. A lebonyolító bizottságok pontosan meghatározzák a könyv terjedelmét, a kivitelezés technikai, grafikai követelményeit, a legolcsóbb ajánlatnak járó (pályázatonként változó) pontértéket. A kézirat tartalmi elbírálását ismeretlen személyekből álló bizottság végzi, elsődleges, kizáró jellegü szempontja a tantervnek való tökéletes megfelelés. Döntéseinek objektivitása - bár értékelési szempontjaikat könyvnyi terjedelmủ jegyzék rögzíti - minden alkalommal megkérdőjelezhető. Az összesített pontszám szerinti rangsorolás (a kézirat tartalma + a majdani könyv tervezett ára) ritkán esik egybe a kézirat minőségének a rangjával. (2004-2005-ben a legalacsonyabb és a legmagasabb árral jelentkező pályázatokat indulásból kizárták, a kézirat elolvasása nélkül.) A jóváhagyott könyvek kiadására, nyomtatására, leszállítására a minisztérium szerződést köt a kiadóval, majd a könyv bekerül a tankönyvkatalógusba. A kiadónak a továbbiakban nincs joga javított kiadást megjelentetni. A gazdasági szempontokat előtérbe helyező, minőségellenes pályáztatási feltételrendszer eredményeként mind a román, mind a magyar tannyelvű oktatást tartalmilag és kivitelezésben is jó minőségú tankönyvektől fosztották meg. A rendszer múködése következetlen és kiszámíthatatlan, minisztercserénként ${ }^{1}$ változik, a megtervezhetőség hiánya ellehetetleníti a szakmai múhelyek, tankönyvszerzők és szerkesztőségek munkáját, felkészülését. 1997 óta egyetlen kiadónak (T3 Kiadó, Sepsiszentgyörgy) sikerült tankönyvsorozat megjelentetése, a pedagógiai szemlélet folytonosságának biztosítása az elemitől a 12. osztályig, és csak egyetlen tantárgyból, magyar nyelv és irodalomból.

Az első pályázatokon, 1998, 1999 és 2000-ben a szerzőnek lehetősége volt a kézirathoz csatolt szinopszisban érvelni a könyv összeállításában érvényesített szempontok ésszerúsége, szükségessége mellett. 2004-tôl - ennek híján - az értékelők a könyvet ízekre szedve próbálták aprólékosan kimunkált, merev szempontrendszer rovatainak sablonjába illeszteni, több eredeti gondolkodású szerző könyvét utasították el csupán a sablonba nem illése okán.

1997-ben jelent meg először pályázaton jóváhagyott magyar alternatív tankönyv: az ábécéskönyvek, majd felmenő rendszerben az elemi oktatás anyanyelvkönyvei. Négy év múlva újabb ábécéskönyv és másodikos magyar, amelyet nem a harmadikos követett, hanem újabb elsős és másodikos 2004-ben, majd harmadikos és negyedikes $(2005,2006)$. Az általános iskola felső tagozatán 1998-ban lehetett először pályázni 5. osztályos könyvvel, 1999-ben hatodikossal, 2000-ben - az addigi tanévenkénti haladás rendjét megbontva - összevonták a 7.-es, 8.-os és 9.-es pályázatokat. İgy a nyolcadikosok úgy kezdték az új tanterv szerinti tankönyvet használni, hogy 7. osztályig a régi szerint tanultak. A középiskolai tantervek jóváhagyására

1 Az utóbbi 22 évben 20 minisztere volt az oktatási tárcának: 1990: Mihail Sora, 1990-1991: Gheorghe Ştefan, 1991-1992: Mihail Golu, 1992-1996: Liviu Maior, 1997: Virgil Petrescu, 19972000: Andrei Marga, 2000-2003: Ecaterina Andronescu, 2003: Alexandru Athanasiu, 2004-2008: Mircea Miclea, Mihail Hărdău, Cristian Adomniţei, Anton Anton, 2008: Ecaterina Andronescu, 2009: Emil Boc, 2009-2012: Daniel Funeriu, Cătălin Baba, Ioan Mung, Liviu Pop, Ecaterina Andronescu, 2012-2013: Remus Pricopie. 
1999-ben, a tankönyvek pályázatára pedig csak 2000-től került sor. 2007 óta a minisztérium nem írt ki tankönyvpályázatot.

2005-ig az oktatási minisztérium nem engedélyezte magyarul megírt tankönyvek indulását a tankönyvpályázatokon. Az 5-8. osztályokban, ahol a pályázatok 2000-ben lezárultak, az anyanyelv és irodalomolvasás, valamint a kisebbségek történelmén kívül minden más könyv fordítás. A 3-4. osztályoknak (a 2. osztály kimaradt) kiírt 2005-2006-os pályázatokon több magyar kiadó is jelentkezett kézirattal, akkor 26 magyar nyelven írt tankönyvet hagytak jóvá. A líceumi tankönyvek késve meghirdetett - a pályázás nyelvét illetően az utolsó pillanatig bizonytalan - pályázataira a magyar kiadók nem tudtak felkészülni, a magyar nyelv és irodalom tankönyveken kívül mindössze 10 magyar nyelvű tankönyv készült el, 2007-ben pedig leállt a pályáztatás.

2005-ig a tankönyvek magyarra fordításáról is a nyertes román kiadók gondoskodtak, ${ }^{2}$ bár „a tankönyvpályázatok eredményeinek jóváhagyása és a tankönyvek értékelése 2001-től a minisztérium, a magyarul megírt vagy magyarra fordított tankönyveké a Kisebbségi Főosztály feladatkörébe tartozott, ennek a feladatnak azonban a Főosztály nem volt képes megfelelni. Belement abba a számára kényelmes megoldásba, hogy maguk a kiadók gondoskodjanak a szakmai és nyelvi lektorálásról”. ${ }^{3}$

A kiadók ennek a feladatnak nem tudtak megfelelni. A nyelvileg igénytelen, magyartalan fordításokban a durva helyesírási hibák mellett tárgyi tévedések is előfordultak. Általánosnak mondható hibájuk, hogy „nem képesek elkerülni a tükörszerkezetek csapdáit, a romános szórendet, és ezt mintha azzal kompenzálnák, hogy az általános használatú nemzetközi terminológiát viszont magyarral helyettesítsék”; ${ }^{4}$ vagy „a fordítás egészében a helyes magyar beszéd elleni merénylet, mely zavaros történelmi fogalmakat szül a tanulók fejében. A nyelvhelyességi szabályok felrúgásának, a sértő magyartalanságoknak a teljes felsorolása lehetetlen”. ${ }^{5}$

A silány minőségű fordítások ügyében szülők, tanárok, civil szervezetek vezetői több ízben fordultak a nyilvánossághoz. Az Erdélyi Tankönyvtanács cím szerint megnevezte a magyar oktatásban alkalmatlannak vagy károsnak tartott tankönyveket, kérte azok átdolgozását, illetve visszavonását: ,Jelenleg legalább 15 olyan tankönyv van a romániai magyar közoktatásban (nemcsak fordítások!), amelyeket vissza kellett volna vonni”. Felhívták a figyelmet a magyar nemzeti közösség kulturális környezetének megfelelő, a hagyományokból adódó nyelvi, képi elemek tankönyvbeli használatának szükségességére: „A magyar tannyelvű könyvek nem válhatnak a román tanulók számára elkészült tankönyvek 'hủ másaivá, magyar szavakban megjelenített tükörképeivé. A kisgyermekek tankönyveiben föllelhető kell hogy legyen a gyermeki lét és az anyanyelvi kultúra összes eleme: a magyar közmondások, szólások, kiszámolók vagy gyermekdalok, a felsőbb korosztályok számára pedig lehetővé kell tenni, hogy

2 20-nál több román kiadó jelentet meg magyarra fordított tankönyveket, legtöbbet az All Educational, a Teora, a Corint, az EDP, Sigma, Humanitas, Radical kiadók.

3 FóRIS-FERENCZI Rita-PÉNTeK János: A romániai magyar közoktatás, különös tekintettel az oktatási nyelv $(e k) r e .=$ Szerk. BARTHA Csilla, NÁDOR Orsolya, PÉNTeK János. Nyelv és oktatás kisebbségben. Kárpát-medencei körkép. Tinta, Budapest, 2011.73-131.

4 PÉnTeк János: A tankönyvírás csapdái és dilemmái. Korunk IX(1998). 9. szám 4-7.

5 VIncze Zoltán: Gondolatok a kötelezö tankönyvekröl. Magiszter 2004. 155-157. 
megismerkedjenek a magyar tudomány és technikatörténet jelentős eredményeivel, személyiségeivel". ${ }^{6}$

A magyar szerkesztőségek 2005-2006-ban vállalkozhattak fordításokra, miután az Erdélyi Tankönyvtanácsnak sikerült megszerveznie a fordítások szaklektorokkal való ellenőriztetésének rendszerét.

Hazai, eredeti tankönyvek híján néhány tantárgyból Magyarországon kiadott tankönyveket is használtak, elsősorban a tanítók/tanárok, minisztériumi jóváhagyás nélkül. Ez indította el - a sajtóban „tankönyvháborúnak” nevezett - tragikomikus hatósági vizsgálódásokat a székely megyékben: úgynevezett „tankönyvkommandók” létrehozását az iskolába igyekvő gyermekek táskájának átkutatására, az iskolai könyvtárak „illegális” térkép- és történelemkönyvállományának felderítésére. ${ }^{7}$

A „tankönyvháborút” kísérő nyilatkozathullámban megszólaltak pártok, civil szervezetek, különböző szintű tisztségviselők határon innen és túl. Az ügy mögött természetesen nem szakmai érvek álltak, hanem politikai megfontolások. Valójában az anyaországi tankönyveket nálunk inkább segédeszközként használhatták, hiszen nem a hazai tantervet követték. A sajtónyilvánosság akkor (tiszavirág-életű) témává emelte a diszkriminatív tankönyvellátást, a magyar oktatás súlyos tankönyvhiányát, megfogalmazódott, hogy nem a magyarországi tankönyveket kellene kutatni magyar iskolákban és könyvtárakban, hanem pénzt adni Romániában nyomtatott magyar nyelvü tankönyvekre, és ellátni a magyar nyelvü iskolákat tankönyvekkel.

\section{AZ ANYANYELV- ÉS IRODALOMTANKÖNYVEK}

A hivatalos tankönyvpályázatok beindulása előtt 6 évvel, 1992-ben két sepsiszentgyörgyi tanár egy tantervpályázati kiírásra alternatív tantervet készített, majd ennek nyomán egy-egy kísérleti tankönyvet az 5. és a 9. osztálynak. A tanterv Jámbor szándék néven vált ismertté (ez a pályamunkájuk jeligéje volt). A Jámbor szándék körül kialakult tanterv- és tankönyvbotrány több olyan problémára is rávilágít, amelyek mind a mai napig éreztetik hatásukat nem csak a tankönyvek, de általában a hazai magyar nyelvü oktatás egészében.

6 SzÉKely Győző: Visszatért a múlt? Könyv és nevelés VII(2005). 3. szám (elérhető http://www. tanszertar.hu/eken/2005_03/2005_03.htm, letöltés ideje: 2013. 10. 01.); SzÉkELY Győző: A tankönyvkiadás sajátos kérdései kisebbségi helyzetben = Tankönyvelméleti tanácskozás, 2001. Szerk. Karlovitz János. Tankönyvesek Országos Szövetsége, Budapest, 2002. (elérhető old.lib.pte.hu/ konyvtarrol/munkatarsaink/dardai/ .../text/.../dardai11.htm, letöltés ideje: 2013. 10. 10.).

7 Tankönyvháború Romániában. Új Szó, 2001. okt. 13.; Tragikomikus a „tankönyvháborü. Szabadság, 2001. okt. 17.; Folytatódik a „boszorkányüldözés”. Vizsgálóbizottságok magyar tankönyvek nyomában. Népújság (Marosvásárhely), 2001. okt. 17.

A Magyar Ifjúsági Konferencia (MIK) Zárónyilatkozata 2001. november 24-én, Eszék (elérhető magyarifjusagikonferencia.eu/wp-content/files_mf/mikzaronyilatkozat_2, letöltés ideje: 2013.10. 13.). 
A pályázatot meghirdető kolozsvári magyar tanszék a beérkező javaslatok közül a Jámbor szándékot fogadta el, ${ }^{8}$ úgy értékelte, hogy a szaktudományos és pedagógiai szempontból is új szemléletű tantervkoncepció nemcsak az irodalomtanítás, hanem a nevelési gyakorlat egészében érvényesíthető tanulási/tanítási folyamat alapjait fejtette ki. 1992-ben 50 példányban megjelentette, ${ }^{9}$ így az érdeklődő kollégák számára is hozzáférhetővé vált.

A pályamunka természetes módon illeszkedett az erdélyi magyar tanártársadalom 90-es évek eleji kezdeményezéssorozatába: nem felső utasításra, hanem belső parancsra láttak munkához az önszerveződő szakmai csoportok, tantervjavaslatokat, új tankönyveket, oktatási segédleteket dolgoztak ki. (1993 októberében a Collegium Transsylvanicum Alapítvány pályázati kiírásán 200-nál több tanító, tanár jelentkezett tankönyvvel vagy más taneszközzel!)

Az új szemléletű tantervről nyilvános szakmai vita ugyan nem alakult ki, de a Jámbor szándék szerzői komolyan vették saját szándékukat, ennek a tantervkoncepciónak az alapján kezdték el a felmenő rendszerben történő tanterv- és tankönyvírást a gimnáziumi és a líceumi tagozatnak. A Collegium Transsylvanicum Alapítvány 1994-es pályázatán mind a tantervkoncepció, mind a tankönyvek pozitív szakmai elbírálásban részesültek. Tulit Ilona 5. osztályos, valamint Orbán Gyöngyi 9. osztályos Megértő irodalomolvasás tankönyvének egy-egy sokszorosított fejezetével indult el - Ferenczi Rita, a bukaresti Neveléstudományi Intézet magyar munkatársának vezetésével - az akkor nálunk még „példátlanul” első tankönyvkísérlet. „A program keretében évharmadonként megbeszélések formájában történt a tankönyv tanításával kapcsolatos tapasztalatok megbeszélése, a tanári beszámolók a tananyaggal való haladás ütemére, a tanítással kapcsolatos problémákra, a mérés-értékelés kérdéseire irányultak. Ehhez szervesen kapcsolódtak a nyaranta tartott tábor formájában szervezett továbbképző tanfolyamok (a Bolyai Nyári Akadémia keretében Szovátán, 1995 szeptemberében, Székelykeresztúron, 1996 augusztusában), amelyen a kísérletben részt vevő tanárokon és tanulókon kívül jelen volt az egyetemi hallgatók egy csoportja és azok a magyartanárok, akik jelezték bekapcsolódási szándékukat”. ${ }^{10}$

A két kísérleti tankönyv 1994-95-ben nyomtatásban is megjelent 600 példányban (alapítványok, magánszemélyek és a T3 Kiadó anyagi támogatásával). Nemsokára szakmai és hatalmi érdekek kereszttüzébe kerültek a könyvek, értelmezhetetlenül durva támadások, nyilvános megszégyenítések érték a szerzőket és a tankönyvkísérletben részt vevő tanárokat egyaránt. Az új szemlélet már nem találta helyét abban a zűrzavarban, amely az oktatás egészét jellemezte. A felső vezetés igyekezett felelőtlen „partizánakciónak” minősíteni a kísérleti tanköny-

8 Овва́n Gyöngyi-Tulit Ilona: Jámbor szándék. Pályamú a magyar filológiai tanszék által meghirdetett tantervpályázatra. Sepsiszentgyörgy, 1992. Máig szerepel ajánlott szakirodalomként a szegedi egyetem tanrendjében: Egyetemi tanrend, Szegedi Tudományegyetem, 2013-2014-1. félév (elérhető www.u-szeged.hu/tanrend?browse=kurzus\&kurzusId...2013-2014-1, letöltés ideje: 2013. 10. 20.).

9 Cs. Gyımesi Éva szorgalmazására, a Transsylvania Alapítvány támogatásával, a Korunk Baráti Társaság közremüködésével. Később Orbán Gyöngyi közli: Megértő irodalomoktatás. Stúdium, Kolozsvár, 1998.

10 Fóris-Ferenczi Rita: Adalékok az erdélyi magyar oktatáskutatás és -fejlesztés történetéhez. 19902001 = Szerk. Tánczos Vilmos, Tőkés Gyöngyvér: Tizenkét év. Összefoglaló tanulmányok az erdélyi magyar tudományos kutatások 1990-2001 közötti eredményeiröl. III. Scientia, Kolozsvár, 2002. (Sapientia Könyvek) 159-209. 
vekkel való munkát, „kísérleti malacoknak” a tanulókat, megpróbálta egymás ellen fordítani a tankönyvkísérletben részt vállaló és abból kimaradó magyartanárokat. Az 5.-es tankönyv szerzőjét az alternatív tankönyv használatáért írásbeli megrovással és fizetésmegvonással büntette meg a minisztérium ellenőrző csoportja. ${ }^{11} \mathrm{Az}$ uszítással megosztott szakmabeliek között - a mesterségesen fenntartott információszegénységben - sokan nem tudták, mi is az a ,jámbor szándék”, a felső vezetés az alternativitás fogalmának téves értelmezésével manipulált. „Megbünhődtek valamiképpen mindazok, akik pl. tankönyvet mertek írni, vagy részt vettek azok kísérleti programba rekesztett tanításában, vagy éppenséggel matematika, fizika stb. tankönyvet vagy oktatási segédletet szerkesztettek" ${ }^{12}$

1997-ben a minisztérium tankönyvpályázatán részt vehettek az első magyar nyelvű tankönyvek, az ábécéskönyvek. Hivatalosan zöld utat kaptak az alternatív tankönyvek: az elemi tagozat tankönyveivel párhuzamosan megjelentek a magyar nyelv és irodalom tankönyvei az általános iskola felső tagozatának (1998-2000 között) és a középiskolai osztályoknak (19992002 között).

Orbán Gyöngyi könyvei nyelvi ismereteket nem tartalmaznak, „ennek ellensúlyozására adta ki az Erdélyi Tankönyvtanács, és fogadtatta el hivatalosan is iskolai használatra Szende Aladár gimnáziumi tankönyvét". ${ }^{13}$

Mire a tankönyvsorozat megjelent, megváltoztak a tantervek. 2001-2003 között sor került a magyar nyelv és irodalom korábbi tantervének teljes átdolgozására, ezáltal "esély adódott az 5-8. osztályos és a középiskolai magyar tantervek korrekciójára. Ez szükséges is volt, hisz eddig nemcsak a szakma körében, hanem a különböző iskolaszakaszok munkacsoportjai között sem alakult ki az együttműködés és szemléleti egyetértés. Nem tisztázódott a tantervi koncepció, a magyar nyelv és irodalom integrációjának értelmezése, a differenciálás kérdése. [...] A 2004-ben a minisztérium által is jóváhagyott tanterv átfogóan rendezte az anyanyelv oktatását az 5-12. osztályban”. ${ }^{14}$ A tanterv készítői és jóváhagyói (Péntek János irányította 25 tagú szakmai bizottság) arra számítottak, hogy annak bevezetése felmenő rendszerben fog megtörténni az oktatási ciklusoknak megfelelően. Az új tantervet követő tankönyvek azonban a mai napig nem készültek el az általános iskola felső tagozatának, illetve elkészültek, de a minisztériumi pályáztatás elmaradása miatt nem jelenhettek meg, a 9. és 10. osztályos köny-

11 Zsehránszky István: Elindultak a tannyomozók. Romániai Magyar Szó, 1996. jún. 24.; Fekete Réka: Miniszteri jelentés magyar nemzetiségü román tanulókról, tanárokról. Háromszék, 1996.jún. 27.

12 Orbán Gyöngyi: Mi az oka, hogy Romániában az oktatói mesterség nem tud lábra kapni? avagy: A megértő irodalomolvasás és szerzóje nem kiván „pozitiv példa” lenni. Szabadság, 1996. nov. 6.; Romániai Magyar Szó, 1996. nov. 9-10; Háromszék, 1996. nov.

13 Ferenczi Rita: Mesterséges szakadék szándékok és lehetöségek között. Szabadság, 1996. nov. 6.; Muzsi Anikó: Gondolatok egy tankönyv-vita kapcsán. Romániai Magyar Szó, 1997. jan. 9.; Kolcsár Irén: Beszélni muszáj ... Romániai Magyar Szó, 1997. febr. 5.; Or Bán Gyöngyi: Levél Muzsi Anikó magyartanárnak a mundér becsületérôl. Romániai Magyar Szó, 1997. febr.19.; Cs. Grimesi Éva: $A$ hivatalnok, akit átmentettünk. Romániai Magyar Szó, 1997. febr. 26.; OrBán Gyöngyi: Ilyen „tudásra” van nekünk szükségünk? Romániai Magyar Szó, 1997. márc. 12.; Ferenczi Rita: Kérdések reformügyben a dolgok tisztázásáért. Romániai Magyar Szó, 1997. ápr. 23.; Murvai László: Koncepciós per '97; Világbank, intervenció avagy a dolgok összekeverése. Románia Magyar Szó, 1997. jan. 18-19.

14 Fóris-Ferenczi Rita-PÉntek János: i. m. 73-131. 
vek pedig „nem váltották be a hozzájuk füzött reményeket”, ${ }^{15}$ a 11-12. osztályoknak Orbán Gyöngyi irodalom könyvei mellé a hivatalos minisztériumi pályázatra nem készült nyelvi ismereteket is tartalmazó tankönyv. Ezért 2004 márciusában az Erdélyi Tankönyvtanács írt ki meghívásos pályázatot, és megszületett, majd jóváhagyást is nyert két új magyar tankönyv (Bara Katalin-Csutak Judit, Balázs Géza-Benkes Zsuzsa Magyar nyelv és irodalom tankönyvei) a 11. és a 12 . osztály számára.

Jelenleg 24 jóváhagyott magyar nyelv- és irodalomtankönyvünk van, évfolyamonként 2-2. Erdélyi és magyarországi (Balázs Géza, Benkes Zsuzsa) szerzők, tanítók, középiskolai, illetve egyetemi tanárok munkái. Az 1-4. osztályos anyanyelvkönyvek szerzői: Lovász AndreaTunyogi Katalin (Stúdium Kiadó, Kolozsvár); Kénosi Dénes Ida (T3 Kiadó, Sepsiszentgyörgy); az 5-8. osztályosoké: Tulit Ilona (5., 6., 7., 8. osztály, T3 Kiadó, Sepsiszentgyörgy), Máthé András-Szász-Mihálykó Mária (5. és 6. osztály, Editura Didactică şi Pedagogică, Bukarest), Cseh Katalin (7. osztály, Editura Didactică şi Pedagogică, Bukarest), Zalány Virág (8. osztály, T3 Kiadó, Sepsiszentgyörgy); a 9-10. osztályosoké: Ambrus Ágnes-Bodó Anna (Stúdium Kiadó, Kolozsvár), Orbán Gyöngyi (T3 Kiadó, Sepsiszentgyörgy); a 11-12. osztályosoké: Bara Katalin-Csutak Judit, Balázs Géza-Benkes Zsuzsa (11. osztály, Corvin Kiadó, Déva; 12. osztály, T3 Kiadó, Sepsiszentgyörgy), Orbán Gyöngyi (T3 Kiadó, Sepsiszentgyörgy).

Mindenik könyv a megírásakor érvényes tanterv szigorú előírásai alapján készült. Az 5-8. osztályos tantervek amellett, hogy zavarosak, túlméretezettek és következetlenek, olyannyira előíró jellegúek voltak, hogy az irodalomolvasás tanítási tartalmaihoz kötelező címlistát is csatoltak. A hatalmas ismeretanyagot számszerúen meghatározott oldalterjedelembe kellett bezsúfolni. A tartalmi előírások mennyisége és a terjedelmi korlátozás a szövegek tördelését, a képanyag elhelyezését, a könyvek általános grafikai képét is indulásból ellehetetlenítette. (A viszonyítás kedvéért jegyzem meg, hogy az 1980-as évek közepén felújított 8.-os könyv 336 oldal terjedelmű, a 2000-ben ezt lecserélő új könyv 208 oldalas.) A tankönyvekről készült néhány értékelés valójában a tantervkészítőket minősíti. ${ }^{16}$

Erdélyben nem honosodott meg a tankönyvkritika. A '90-es évek derekán oda jutottunk - vezető tisztségviselők uszító, megosztó beavatkozása nyomán -, hogy a közös érdeket szolgáló bírálatot személyeskedésnek kezdték tekinteni, a jobbító szándékot a felségterületekbe való illetéktelen beavatkozásnak. Hetek, hónapok, sőt évek teltek el egy-egy könyv megjelenése után úgy, hogy senki nem mondott róla véleményt nyilvánosan. A szakszerű tankönyvkritikát a „suttogó propaganda” helyettesítette.

Az új, alternatív tankönyvekre általában nem úgy tekintettek, mint amelyek egy nagyon természetesen jelentkező társadalmi elvárásnak tesznek eleget, inkább úgy, mint amelyek a régiek ellen készülnek, az alternatív tankönyvek pedig egymás ellen irányulnak. A szakmabeli-

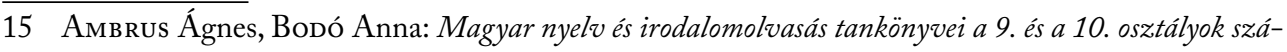
mára.

16 Kántor Emese: Férfi-sztereotípiák a Tulit Ilona-féle tankönyvekben. XIII. Erdélyi Tudományos Diákköri Konferencia, Kolozsvár, 2010. máj. 14-16. (elérhető etdk.adatbank.transindex.ro/pdf/mit_ kantor.pdf, letöltés ideje: 2013. 10.20.); NAGY Anna: Miért nem szökik meg Kömíves Kelemenné? Hogyan olvasnak népballadát a hetedikes irodalomtankönyveink? (elérhető epa.oszk. hu/00300/00384/00094/.../EPA00384_lato_2011_06_2093.pd., letöltés ideje: 2013. 10. 20.); BölöNi Domokos: Alternatîv tankönyvek. Búcsú a János vitéztöl? Népújság, 1998. júl. 16. 
ek többsége örömmel és bizalommal fogadta Tulit Ilona tankönyveit, a választás lehetőségére és felelősségére is figyelmeztetve, a „hivatal” általában nem ajánlotta, néhány megyében a szakfelügyelő nyíltan tiltotta vagy akadályozta a használatukat. Kinevezték elithez mért, „nehéz”, „túl igényes” könyvnek, noha a kollégák nagyobbik része első perctől úgy tartotta, hogy „a szelídség, a jóság, a biztatás szól az egész tankönyvből, ahogy a szerző kinyújtja kezét a tanár és a kisdiák felé, a világra és önmagukra nyitja a gyermekek szemét” ${ }^{17}$ A sorozat első darabjáról, az 5.-esről írt részletes és igényes értékelést ${ }^{18}$ az újságok és szaklapok terjedelmi okokra hivatkozva nem vagy csak részleteiben közölték, a könyvbemutatókra „elfelejtették” a könyvet elküldeni, a tanároknak sok helyütt úgy kellett „választaniuk” az alternatívákból, hogy a tankönyveket nem is látták, a könyvrendelési lapokat tudtuk nélkül (intézményvezetők, szakfelügyelők) utólag módosították. A sorozat következő darabjairól kevés hír jelent meg, voltak (főként) szóbeli visszajelzések kollégáktól és bírálatok a hivataltól, valójában a szakma a tankönyveket agyonhallgatta. A sors fintora, hogy a minisztérium ésszerütlen pályáztatási rendszerének köszönhetően éppen ezek a könyvek maradtak leghosszabb ideig használatban, (1998-tól) mai napig is változatlan formában.

Ellentmondásosan fogadta a szakma Orbán Gyöngyi hermeneutikai irodalomszemléletű tankönyvsorozatát. A taníthatóság, a megérthetőség irányából támadták leginkább, mások éppen azt értékelték, ahogyan a szerző „élményszerûvé, életközelivé teszi..., a talán nehezen érthető problémákról is a legnagyobb természetességgel, barátságos hangnemben folytat párbeszédet a tanulóval. [...] Lehet, hogy a tankönyv sokak számára túl'magasnak' tünik, mégsem az. Csak igényes. Márpedig ez egy középiskolai tankönyvnek úgymond kutya kötelessége”. ${ }^{19}$ Többen is érzékelték és értékelték az alternatív tankönyvek által elindított szemléletbeli változást az irodalomtanításban. ${ }^{20}$ A szerző két kötetben megjelentetett tanulmányai tanári kézikönyv szerepét is betöltötték, ${ }^{21}$ az új irodalomszemlélet megértéséhez és alkalmazásához nyújtottak segítséget a sepsiszentgyörgyi T3 Kiadó Pedagógus Mühely sorozatában megjelentetett könyvek. ${ }^{22}$

Fontos eredménynek számított 2004-ben az új tanterv szerinti - amely a középiskolai osztályokban is megfelelő súllyal írja elő a nyelvi ismeretek tanítását - 9.-es magyar nyelv és

17 KolcsÁr Irén: Munkáltató tankönyvek. Korunk IX(1998). 9. szám, 120-121.

18 Orbán Gyöngyi: Tankönyv a teremtö embernek. Szabadság, 1998. júl. 4.

19 Farmati Anna: Alternativitás a középiskolai irodalomtanitásban. Korunk IX(1998). 9. szám, 116119.

20 Gомвоs Márta: Az irodalomtanitás szemléleti változása www.rmpsz.ro/web/images/magiszter/2005_osz/1.pdf; Hevesi Zoltán István: Drámapedagógia és irodalomtanitás - egy hermeneutikai szemléletú pedagógia esélyei a globalizáció korában Anyanyelvi kultúraközvetítés I(2012).1. szám; LAкATOs István: Egy befogadóorientált tankönyvcsalád hermeneutikai megértéskoncepciójáról. Új Pedagógiai Szemle LVIIII(2009). 9. szám.

21 Orbán Gyöngyi: Megértő irodalomoktatás. Kolozsvár, Stúdium, 1998.; Orbán Gyöngyi: Háttérelemzések. KOMP-PRESS Korunk Baráti Társaság, Kolozsvár, 2000.

22 Fóris-Ferenczi Rita- Orbán Gyöngyi-Székely Melinda-Vincze Kata Zsófia-Zágoni Melinda: Beszélgetôkönyv a megértó irodalomoktatásról. Szerk. Fóris-Ferenczi Rita, T3, Sepsiszentgyörgy, 2003.; Antal Margit-Márton Kalapáti Jolán-Orbán Enikő: Az irodalomtanitás öröméért. Szerk. Tulit Ilona, T3, Sepsiszentgyörgy, 2005.; Antal Margit-Miszt rik Jolán-Orbán Enikő-Patek Mária-Szilveszter László Szilárd: Az irodalomtanitás öröméért. II Szerk. Tulit Ilona, T3, Sepsiszentgyörgy, 2006. 
irodalom tankönyv (Ambrus Ágnes és Bodó Anna munkája, kiadta a kolozsvári Stúdium Kiadó) megjelenése. Nem bizonyult sikerkönyvnek. Péntek János véleménye szerint „ha ezzel marad a 9. osztályos magyar nyelv- és irodalomoktatás, akkor az semmiképpen nem jelent előrelépést, inkább csak az igénytelenségbe való beletörődést. Korábban az volt a helyzet, hogy ezt a tantárgyat is felülról irányították, cenzúrázták a tankönyveket, de az akkori körülmények között a nyelvi igényesség, a didaktikai szempontok és szakmai követelmények inkább érvényesültek mind a tankönyvírásban, mind a tankönyvek kiadásában. Én ezt nem hoznám összefüggésbe azzal, hogy akkor a tankönyvek körüli szakmai kör lényegesen szélesebb volt: gyakorló tanárok, egyetemiek, szakfelügyelők egyaránt részt vettek benne. Most a másik végletnél tartunk: szúk szakmai csoport állítja kész helyzet elé tanártársait (és a tanulókat) azzal, hogy a hályogkovács bátorságával, alaposság, kelló türelem és körültekintés nélkül, sietve áll elő a kész tankönyvvel”. ${ }^{23}$

2005-ben a szerzőpáros a 10. osztályos könyvet is elkészítette, azóta is az érvényes tankönyvek jegyzékében szerepel mindkettő.

Megállapítható, hogy „máig nincs ennek az oktatásunkat megalapozó és integráló tantárgynak korszerúen kidolgozott, tankönyvekkel és más oktatási anyagokkal felvértezett tanterve". ${ }^{24}$

\section{A MINISZTÉRIUM TANKÖNYVKATALÓGUSA A 2013/14-ES TANÉVRE}

A 2013-2014-es tanévre szóló tankönyvjegyzék 251442 címet tartalmaz a 2-12. osztályoknak: 973-at a 2-10.-nek, 469-et a 11-12.-nek. Az idei jegyzékben nem szerepelnek az 1. osztályosok könyvei, a minisztérium számukra már 2013 őszétól új tankönyvek bevezetését tervezte. (Amikor nyilvánvalóvá vált, hogy az elképzelés nem megvalósítható, utasította a tanfelügyelőségeket a régi könyvek utánrendelésére.)

A tankönyvjegyzékben szereplő könyvek minőségéről nem alkothatunk megnyugtatóan objektív képet, hiszen a tankönyvírás és tankönyvkiadás folyamatát nem kísérte folyamatos értékelés. Mindenképpen figyelmet érdemel, hogy mit kínál a tanügyminisztérium a magyar anyanyelven tanuló diákoknak (és tanítóiknak/tanáraiknak) tantárgyak, szerzők, a megírás nyelve, kiadók, kiadási év szerint.

A tankönyvjegyzékben feltüntetett tankönyvek 11,8\%-a (172 cím) készült a magyar nyelven tanulóknak. Oktatási ciklusokra lebontva: a 2-4. osztálynak: 14,7 \% (a 251-ből 38 cím), az 5-8. osztálynak: 22,2 \% (a 341-ből 76 cím), a 9-10. osztálynak:12,5 \% (a 381-ből 48 cím), a 11-12. osztálynak: 2,1\% (a 469-ből 10 cím). Szembetűnő, hogy míg 5. osztálytól kezdve fo-

23 PÉntek János: Magyar nyelvi ismeretek egy új tankönyvben (elérhető www.rmpsz.ro/web/images/ etankonyvtar/tanulmanyok/m_ny, letöltés ideje: 2013.10.21.).

24 PÉntek János: Tulit Ilona laudációja = Nyelvét megtartó közösség - közösségét megtartó nyelv. Szerk. Erdély Judit, Ördög-Gyárfás Ágnes, Ördög-Gyárfás Lajos, PÉntek János. Sepsiszentgyörgy, Anyanyelvápolók Erdélyi Szövetsége, 2012.144.

25 Catalogul manualelor scolare valabile în învăţământul preuniversitar an şcolar 2013-2014. Közreadja: Ministerul Educaţiei Naţionale, Centrul Naţional de Evaluare şi Examinare / www.edu.ro 
kozatosan nő a tantárgyak/tankönyvek száma, a magyar nyelven tanulóknak készült könyvek száma erőteljesen csökken.

\begin{tabular}{|c|c|c|c|}
\hline \multirow[t]{2}{*}{ osztály } & \multirow{2}{*}{$\begin{array}{c}\text { összes tankönyv } \\
1442\end{array}$} & \multicolumn{2}{|c|}{$\begin{array}{l}\text { magyar nyelven tanulóknak } \\
\text { készült tankönyv }\end{array}$} \\
\hline & & 172 & $11,8 \%$ \\
\hline 2-4.o. & 251 & 38 & $14,7 \%$ \\
\hline 5-8. o. & 341 & 76 & $22,2 \%$ \\
\hline 9-10. о. & 381 & 48 & $12,5 \%$ \\
\hline 11-12. о. & 469 & 10 & $2,1 \%$ \\
\hline
\end{tabular}

A magyar nyelven tanulóknak készült 172 könyvből 8 cím a kisebbségeknek szánt román nyelv és irodalom. A 164 magyar nyelvü könyvnek 32,5 \%-a (54 cím) eredeti, magyar nyelven készült tankönyv, 67,5 \% (110 cím) fordítás.

Magyar nyelvü tankönyvek:

\begin{tabular}{|c|c|c|c|c|}
\hline osztály & összesen & fordítás & eredeti & megjelenés éve \\
\hline & $\mathbf{1 6 4}$ & $\mathbf{1 1 0}$ & $\mathbf{5 4}$ & $\mathbf{1 9 9 8 - 2 0 0 7}$ \\
\hline & & & & \\
\hline 2-4. o. & 34 & 7 & 27 & $2004-2006$ \\
\hline 5-8. о. & 72 & 63 & 9 & $1998-2000$ \\
\hline 9-10. о. & 48 & 39 & 9 & $2005-2007$ \\
\hline 11-12. o. & 10 & 1 & 9 & $2005-2007$ \\
\hline
\end{tabular}

Az 54 eredeti tankönyvet 6 hazai kiadó adja ki: a sepsiszentgyörgyi T3 Kiadó (20 cím), a kolozsvári Ábel Kiadó (14 cím) és Stúdium Kiadó (11 cím), a bukaresti Editura Didactica și Pedagogica (7 cím), a dévai Corvin Kiadó (2 cím). A magyar nyelven megírt 54 tankönyv tantárgyak szerint a következőképpen oszlik meg: 22 magyar nyelv és irodalom, 10 vallástan, 5 matematika, 3 természetismeret, 3 ének-zene, 2 polgári nevelés, 2 történelem, 2 fizika, 2 technológia, 2 informatika, 1 földrajz.

Románból fordított tankönyvek között előfordulnak a következő tantárgyak: matematika, környezetismeret, természetismeret, történelem (a 2-4. osztályban); matematika, fizika, kémia, biológia, ének-zene, művészeti nevelés, technológia, földrajz, történelem, polgári nevelés (az 5-8. osztályban). A 9-10. osztályban az anyanyelv és irodalmat, két vallástant, valamint 1 fizika- és 2 technológiakönyvet leszámítva az összes többi fordítás. A 11-12.-eseknek az anyanyelv- és irodalom- mellett van 2 matematika-, 2 informatika- és 1 fizikakönyvük.

A tankönyvjegyzék adatai szerint a román nyelven tanuló diákoknak tantárgyanként legkevesebb 3 változatot biztosítanak, esetenként 5-6-ot vagy 10-nél is többet, míg a magyar diákoknak ritkán kínálkozik alternatíva, a 2-4. és a 9-12. osztályokban jellemzőbb az egyetlen tankönyv, illetve az egy sem. A katalógusban felsorolt címek közül 64-ből ugyanis fordítás sem készült (10. osztály: 12 cím; 11 . osztály: 30 cím; 12 . osztály: 22 cím). 
Az elemi tagozat tankönyvei 2004-2006 között jelentek meg, a középiskolaiak 20052007-ben, az általános iskola felső tagozatának 1998-2000 között, vagyis utóbbiak a tankönyvpiac legöregebb tankönyvei. Újranyomásukról évente rendelkezik a minisztérium ${ }^{26}$ váltakozó, de mindig elégtelenül alacsony százalékban. (A 2013-14-es tanévre országos szinten 20 millió lejt különített el a minisztérium tankönyvek újranyomtatására. Ez 4 lejes egységárral számolva 600-700 példányt jelent könyvcímenként.)

2007 óta a minisztérium nem írt ki tankönyvpályázatot, a vizsgált tankönyvjegyzék tehát a hat évvel ezelőtt kialakult és azóta változatlan helyzetet tükrözi.

A tankönyvjegyzék, mint már utaltam rá, a törvény által kötelezett minisztériumi jóváhagyással bíró (és ezáltal az iskolai oktatásban használható) tankönyveket tartalmazza. A magyar tannyelvú oktatásban használatosak jóvá nem hagy(at)ott tankönyvek is. A kolozsvári Âbel Kiadó honlapján szereplő könyvkínálatban találhatóak olyan, középiskolásoknak készített tankönyvek (8 cím), amelyek hiányoznak a minisztérium jegyzékéből. Valószínú, hogy minisztériumi engedély nélkül is sikeresen használják, ezek a könyvek azonban nem ingyenesen kerülnek az iskolákba, (a tanár javaslatára) a diákok megrendelik és megvásárolják.

Nem szerepel a minisztériumi jegyzékben a tankönyvnek is szánt - és a román médiában ennek megfelelően támadott - A székelység története, sem a román tannyelvű iskolákban tanuló csángómagyar gyermekeknek készített könyvek. ${ }^{27}$

Az oktatási minisztérium 2013 tavaszától tervezi az e-tankönyvek bevezetését. A folyamat előkészítetlensége miatt erre tanévkezdéskor nem került sor, de szándékáról nem mondott le. A papíralapú tankönyvhöz egy CD-re rögzített változatot is kér: a teljes nyomtatott változatot pdf-formátumban, interaktív tanulási gyakorlatokkal, oktató játékokkal, animációkkal, filmekkel stb.

Közviták, egyeztetések zajlanak, a kiadók a technikai megoldások részleteit, anyagi vonzatát vizsgálják. Nincs tudomásunk arról, hogy magyar szakmai műhelyek és kiadók munkához láttak volna.

\section{KÖVETKEZTETÉSEK}

A minisztériumi tankönyvjegyzék adatait a tankönyv-pályáztatási rendszer, valamint a tankönyvfordítási anomáliák ismeretében vizsgálva megállapíthatjuk:

1. A hazai tankönyvpiac elavult. 16. tanévüket kezdő (egyszer sem javított) tankönyveket is kínál, az 5-8. osztályoknak készült könyvállomány egésze 2000 előtti;

26 Ordin privind completarea stocurilor de manuale şcolare pentru învăţământul obligatoriu pentru anul şcolar 2013-2014, prin achiziţionarea manualelor şcolare retipărite Nr. 3588/22.04.2013 (elérhető administraresite.edu.ro/index.php/articles/19496, letöltés ideje: 2013. 10. 10.). Az újranyomtatást a CNEE (Centrul National de Evaluare si Examinare) koordinálja. A megyei tanfelügyelőségek hatáskörébe tartozik, hogy az érintett kiadókkal megkössék az újranyomtatási szerződéseket, természetesen a minisztérium által erre a célra kiutalt pénzügyi keret lehetőségein belül.

27 A székelység története. Kézikönyv és tankönyv az általános iskolák VI. és VII. osztályai (valamint minden érdeklödö) számára. Szerk. Ferencz S. Alpár, Hermann Gusztáv Mihály, Novák Károly István, Orbán Zsolt. Hargita Megye Tanácsa, 2012.; ábécéskönyv, szöveggyüjtemények (elérhető www. csango.ro > Oktatás > Oktatási anyagok, letöltés ideje: 2013.10.10.). 
2. Az érvényes programok 49,7 \%-ához nem készült tankönyv;

3. A tanügyminisztérium nem biztosította a tantervváltozásokhoz igazodó tankönyvcserét vagy javított kiadások megjelentetését;

4. Nem gondoskodott a választható tantárgyak, a szakoktatás és a speciális oktatás tankönyveinek biztosításáról;

5. Az utánnyomásokra fordított pénzalap elégtelensége miatt a könyveket - a tervezett 3-4 évet jóval túlhaladva - a teljes elrongyolódásig használtatják;

6. Durván diszkriminálta a magyar nyelvű oktatást: a 11-12. osztályokat mondhatni tankönyvek nélkül hagyta, egyetlen cikluson sem biztosította az alternativitást a többségi oktatásban érvényesüló szinten;

7. Elutasította az eredeti, magyar nyelven írt tankönyveket, helyettük románból fordított, többségében gyenge minőségú változatokat engedélyezett, elsorvasztva a magyar pedagógusok szakmai alkotó múhelyeit;

8. Engedélyezett ehelyett didaktikailag, tudományosan megalapozatlan, az oktatási folyamatra nézve kimondottan káros fércműveket „segédkönyv”, „munkafüzet” gyanánt, amelyeket a mai napig forgalmaznak;

9. Az elemi és az általános iskolai oktatás számára kiadott úgynevezett „kisebbségi” román nyelv és irodalom tankönyvek alkalmatlanok az államnyelv hatékony oktatására a magyar iskolákban. ${ }^{28}$ Noha a 2011 januárjában érvénybe lépett új romániai oktatási törvény előírja, hogy a nem román anyanyelvú diákok számára a román nyelvet a kisebbségi nyelvi beszélőkhöz igazított tanterv, tanmenet szerint kell oktatni az erre a célra írt, sajátos tankönyvekből a közoktatás valamennyi szintjén, ezeknek a tankönyveknek az elfogadásáról a minisztérium még nem rendelkezett;

10. A magyar nyelv és irodalom oktatásának súlyos intézményes és szakmai gondjai vannak;

11. A kisebbségi magyar oktatáspolitikát képviselők átfogó stratégia nélkül, alkalomszerűen múködnek közre adott problémák megoldásában.„A romániai magyar közoktatásnak sem a szakmai intézményi háttere, sem a szakmai felügyelete nem biztosított. Az oktatási hatóság felső szintjein és a megyei tanfelügyelőségeken vezető funkciókban biztosítva van a magyar képviselet. A képviselet azonban önmagában nem lehet hatékony, ha a vezetők mellett nincsenek szakemberek, nincsenek szakmai múhelyek. Márpedig a szakmai megalapozás, a szakmai felügyelet, a minőségbiztosítás és irányítás legfontosabb intézményei teljesen hiányoznak. A román minisztérium háttérintézményei a magyar oktatással nem foglalkoznak. Helyettük mindezt rögtönözve végzik a minisztérium magyar tisztségviselői által felkért, társadalmi munkában dolgozó bizottságok (tanterv, minőségmérés, teljesítménymérés, tesztek, vizsgatételek kidolgozása, fordítása stb.). Nincs arra szakosodott intézmény, sem arra szakosodott, azért felelősséggel tartozó szakember, aki tanterveket írjon, aki teszteket, vizsgatételeket dolgozzon ki, aki a minőségmérés szakembere, aki a tankönyvírás, -fordítás szakembere”. ${ }^{29}$

28 BENő Attila: Hogyan tanulják a magyar gyerekek a román nyelvet az erdélyi iskolákban? Székelyföld XVI(2012). 5. szám 123-131.

29 PÉntek János: A magyar tehetség esélyei Erdélyben = A Kárpát-medencei tehetséggondozás jó gyakorlatai. Szerk. Demeter József. Magyar Tehetségsegítő Szervezetek Szövetsége, 17. 
12. Félő, hogy az e-tankönyvek bevezetésének előkészületeiből kimaradva, akárcsak a 90es évek derekán, a magyar nyelvű oktatás ismét lépéshátrányba, majd kényszerüségből csapdahelyzetbe kerül, a jó elképzelések megrekedhetnek a ,jámbor szándék” szintjén.

\section{FROM „GOOD INTENTION”TO E-SCHOOLBOOKS. ON HUNGARIAN SCHOOLBOKS IN TRANSYLVANIAN PUBLIC EDUCATION}

\section{Keywords: original schoolbook, schoolbook translation, book register, schoolbook criticism, schoolbook tender}

The present study analizes schoolbook stocks designed for Hungarian public education in Romania based on the 2013-2014 school year book register issued by the Ministry of Education.

Quantitative indicators are interpreted in correlation with jurisdiction influencing quality of books and proceedings of tender. The process of issuing new Hungarian language and literature curricula and schoolbooks is presented (from 1992), as well as the consequences of introducing e-schoolbooks to be expected.

DE LA „BUNA INTENŢIE” LA E-MANUELE. DESPRE MANUALELE MAGHIARE DIN ÎNVĂŢĂMÂNTULUI PUBLIC DIN TRANSILVANIA

\section{Cuvinte-cheie: manuale originale, traducere de manuale, critica manualelor şcolare, invățământ public din Transilvania}

Studiul analizează manualele școlare destinate învăţământului public maghiar din Romania bazându-se pe Catalogul manualelor școlare valabile în învățământul preuniversitar, an școlar 2013-2014, Ministerul Educației Naționale. 